\title{
Baseline Climatology of Viti Levu (Fiji) and Current Climatic Trends ${ }^{1}$
}

\author{
Melchior Mataki, Kanayathu C. Koshy, and Murari Lal²
}

\begin{abstract}
In this paper we characterize the climate at Nadi and Suva in Fiji from 1961 to the present, providing a picture of ongoing climate trends. The focus is on surface observations of air temperature and rainfall, although some information on South Pacific Ocean climate is also discussed, given its relevance for Fiji. Our findings suggest that surface air temperatures have registered increasing trends at both Suva and Nadi (the two observatory sites in Fiji identified as Weather Observing Stations under the global network of the World Meteorological Organization) during the period 1961-2003. There has been a steady increase in the number of days per year with warmer nighttime temperatures in recent decades. The rise in annual mean surface air temperature over Suva was $\sim 1.2{ }^{\circ} \mathrm{C}$ over the $43-\mathrm{yr}$ period considered here (at a significantly increasing rate of $0.25{ }^{\circ} \mathrm{C}$ per decade, which is 1.5 times higher than the trends in global average temperature increase during the past century). The rate of increase in annual mean surface air temperature at Nadi was $0.07^{\circ} \mathrm{C}$ per decade. No trend in annual mean rainfall has been observed, however, at either of the locations. Significant interannual variability in annual as well as summer rainfall observed at both sites (including extreme rainfall events during the 43-yr period) can largely be attributed to El Niño-Southern Oscillation (ENSO) events and intraseasonal oscillations in the mean position of the South Pacific Convergence Zone.
\end{abstract}

Baseline Climatological data characterize climate during a recent period, serving as a reference against which to compare both historical and likely future climate variations. By international meteorological convention, the baseline climate is usually of $30 \mathrm{yr}$ duration. This is long enough to encompass characteristic interannual and interdecadal variations in climate and to capture a range of short-term extreme climate events but still short enough to allow comparison (for the major climatic variables such as temperature

${ }^{1}$ This study was undertaken as part of the activity under the research project "Integrated Methods and Models for Assessing Coastal Vulnerability and Adaptation to Climate Change in Pacific Island Countries" funded by International START Secretariat, Washington, D.C. Manuscript accepted 29 April 2005.

2 Pacific Centre for Environment and Sustainable Development, The University of the South Pacific, P.O. Box 1168, Laucala Bay Campus, Fiji Islands (fax: +6793232891; e-mail: mataki_m@usp.ac.fj).

Pacific Science (2006), vol. 60, no. 1:49-68

(C) 2006 by University of Hawai'i Press

All rights reserved and precipitation) with earlier periods and hence detection of possible longer-term changes in climate.

\section{Climatological Normals}

In the last two scientific assessment reports of the Intergovernmental Panel on Climate Change (IPCC) (IPCC 2001a,b), the period 1961-1990 was adopted as the climatological baseline, an official World Meteorological Organization "normal" period. Conventionally, these periods repeat at $30-\mathrm{yr}$ intervals, the next being 1991-2020. Notwithstanding this convention, with most climatological data now available in digital form, it is a fairly straightforward exercise to update 30 -yr averages on a decadal basis, and some countries have published climatological summaries for the period 1971-2000.

In selecting the baseline period, one issue to bear in mind is the closure of many manned weather stations worldwide during the 1980s and 1990s and their partial replacement with automatic weather stations. This has posed some problems for maintaining 
high-quality, homogeneous records of climate in many regions. It has also reduced the total number of sites in the observational network, meaning that the station coverage and density for the 1971-2000 data are often poorer than in the earlier (1961-1990) period. This paper therefore is confined to the baseline period of 1961-1990 as standard World Meteorological Organization climatology in the analysis of "climatological normals" of surface air temperature and rainfall at Nadi and Suva stations.

\section{Geographic Location and Key Weather Characteristics}

Fiji consists of $18,376 \mathrm{~km}^{2}$ of land and includes about 330 islands, of which about 100 are inhabited. The largest island and population center is Viti Levu, which has an area of $10,388 \mathrm{~km}^{2}$ (Figure 1). Viti Levu is characterized by high mountains, dry on the leeward west side (Nadi) and wet on the windward east side (Suva). Vanua Levu, located northeast of Viti Levu, is the second largest island and is slightly more than half the size of Viti Levu. Taveuni lies to the east of Vanua Levu. Equal in size to Taveuni is Kadavu, which lies to the south of Viti Levu. Fiji's remaining islands are small and are divided into three main groups: Lomaiviti, Lau, and the Yasawas.

Fiji lies in the South Pacific trade-wind belt of predominantly southeasterly winds. The southeasterlies are relatively strong and persistent in winter (between May and October). In summer (between November and April) the winds are generally light and variable with a predominant sea breeze during the day. Winds from the northerly quarter are also quite common during this period because the South Pacific Convergence Zone lies just to the north of Fiji where the southeast trades and the divergent easterlies converge. Fiji's climate is tropical. Overall, temperatures in summer are slightly higher than in the winter months as is the humidity and the resulting rainfall. The two seasons are largely controlled by the north to south movements of the South Pacific Convergence
Zone, and rainfall distribution is largely controlled by the large-scale cloud bands associated with the convergence zone, the migrating low pressure systems, the movement of the tropical upper tropospheric troughs, and surface midlatitude systems such as cold fronts moving across from the south. From November to April, the Fiji Islands are frequented by tropical cyclones originating in the Pacific Ocean, which results in prolonged heavy rainfall and flooding of low-lying coastal areas. However, the weather in Fiji varies considerably between island regions. This is due to the dominant southeast trade winds, which helps clouds form over the mountains on the southeastern side of the larger islands.

Nadi is situated on the western side of Viti Levu (Fiji's western division). The western division (Sigatoka to Rakiraki) is a relatively dry zone and is subject to large seasonal and interannual climatic variation. The annual rainfall in the dry zones averages around $200 \mathrm{~cm}$. Typically, winter weather in the Nadi region has clear or partly cloudy skies, much sunshine, a well-developed west to northwesterly sea breeze by day (southeasterlies are predominant at night and in all months except from August to March when wind is generally from the northwesterly quarter), and relatively cool nights. In summer, thunderstorm activity is common and responsible for brief spells of high-intensity rainfall. Suva, the capital of Fiji, is situated on the wet eastern side of the island of Viti Levu (in Fiji's central division where the annual rainfall ranges from $300 \mathrm{~cm}$ around the coast to $600 \mathrm{~cm}$ on the higher mountains).

The Fiji group of islands is surrounded by a huge body of water and is affected by globaland regional-scale climatic events such as El Niño and La Niña resulting from interannual variations of the strength of the "Walker Circulation" over the equatorial Pacific Ocean and associated droughts and/or floods, tropical cyclones, and high waves. The islands have experienced extreme weather events recently. In 2003, tropical cyclone Ami devastated parts of Vanua Levu, Tavueni, and the islands in the Lau Group. Heavy rain associ- 


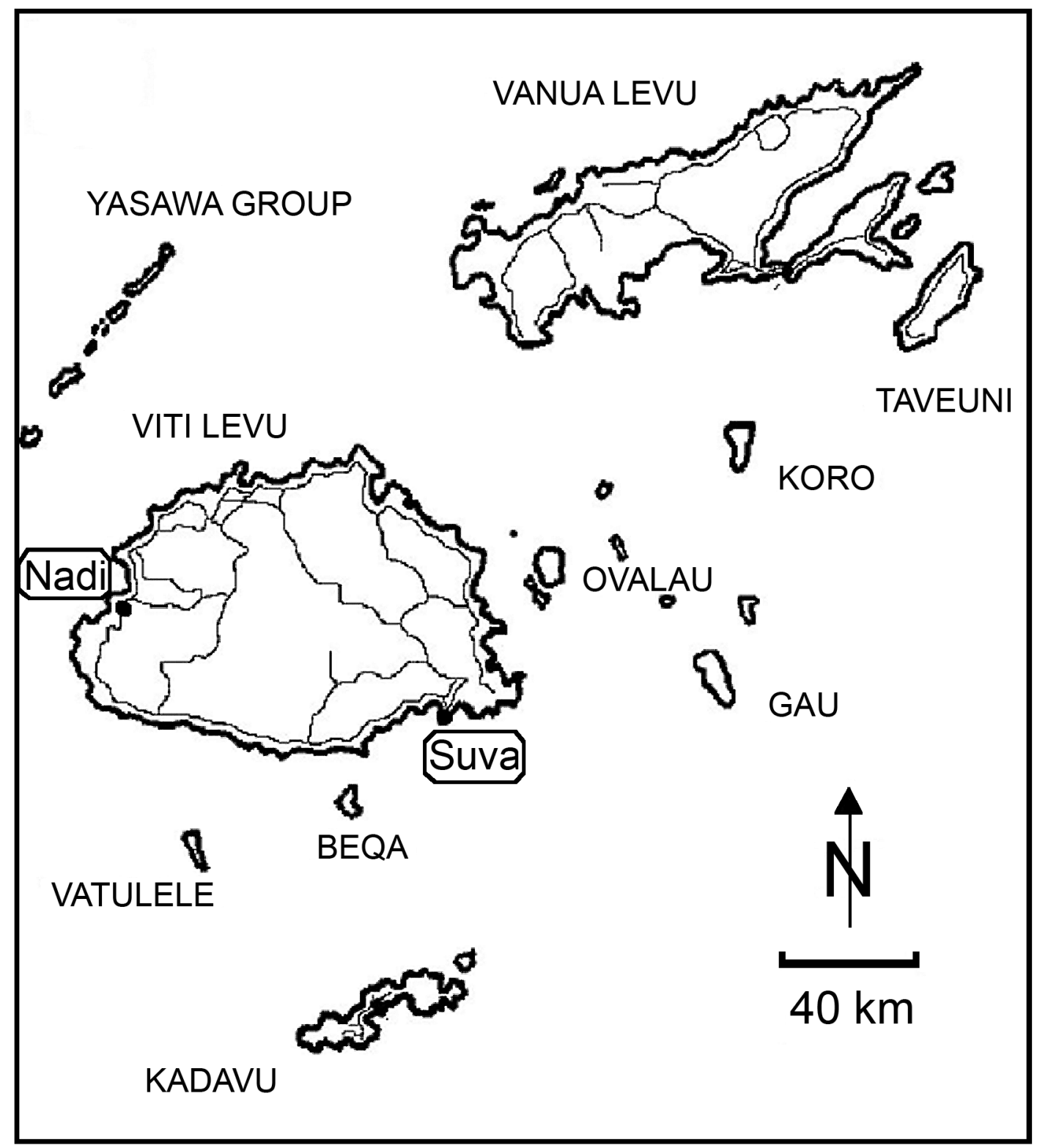

Figure 1. The Fiji Islands showing location of Nadi and Suva sites on Viti Levu.

ated with the cyclone brought widespread floods in Vanua Levu and other parts of the country. Floods of rare magnitude such as one in the summer of 2000 occurred in western Viti Levu leaving many homes under water and millions of dollars worth of damage. In 1998 western Viti Levu, northern Vanua Levu, and islands in eastern Fiji suffered a severe drought that almost crippled the sugar industry, stressing moisture-reliant and non- 
heat-tolerant flora and fauna, resulting in loss of biodiversity. The cost to the central government for relief and recovery, such as food and water, fertilizers, cane seeds, etc., was hundreds of millions of dollars.

However, until now only fragmented studies on a few meteorological variables have been done on the climatological details of Nadi and Suva, and no systematic study on the subject exists as a published document. A general account of the climate and weather of Fiji was provided by Derrick (1951) identifying three classes of regional climate for the Fiji Islands. A similar treatment of the subject was given by Twyford and Wright (1965) but with lesser details. An updated and comprehensive review of Fiji's weather and climate during the period from 1950 to 1975 was published by Prasad (1979). Some aspects of the climate of the Nadi region for planning purposes were also reported in Sharma (1982) and Krishna (1989). Databases offering mean baseline climatology and current trends in surface air temperature and rainfall at selected meteorological stations in Fiji are, however, crucial for assessing the impact of any changes in climate and its variability on various sectors of the economy in the region. Keeping this in view, the findings on the analysis carried out and reported here may provide a helpful reference.

\section{MATERIALS AND METHODS}

The study reported here is based mainly on climatological observations made at Nadi (civil aviation compound, Korowai Road in Namaka) and Suva (Laucala Bay) during the period from 1961 to 2003. Although meteorological data records exist from 1942 for both stations at Fiji Meteorological Service, the data for the period 1942 to 1960 are considered not reliable because they have not undergone quality control checks and contain large gaps; hence in this study we did not use that data. The Fiji Meteorological Service provided the daily data for maximum and minimum temperatures and rainfall for Suva and Nadi for the period from 1961 to 2003 from its climate database. The meteorological observations at the civil aviation compound in Namaka in Nadi $\left(17.75^{\circ} \mathrm{S}, 177.45^{\circ} \mathrm{E}\right.$ ) and at Laucala Bay in Suva $\left(18.09^{\circ} \mathrm{S}, 178.27^{\circ} \mathrm{E}\right)$ can be considered generally representative to within $10 \mathrm{~km}$ of the two sites considered in this study.

The daily temperature and rainfall data for the baseline period from 1961 to 1990 were analyzed to obtain monthly and annual climatological means (also referred to as "normals"). Subsequently, a time series analysis was carried out using the daily data for the period 1961 to 2003 to find monthly, seasonal, and annual anomalies and to investigate any significant changes in the trends and periodicity in the surface air temperature and rainfall of the two locations over the period on a seasonal, annual, and decadal basis. Further, the observed instances of and trends in extreme weather events such as number of hot days, number of wet and dry spells, and recurrence periodicity of droughts and floods were examined as part of the climatology of the selected sites.

An attempt has also been made to interpret and explain the observed trends, periodicity, and extreme events on a seasonal, annual, and decadal basis. For this purpose, we performed stringent statistical tests using analysis of variance (ANOVA) (MINITAB and SPSS software). Possible links between changes in total precipitation and frequency of extremes were explored including the influences, if any, due to El Niño and La Niña teleconnections and the intraseasonal oscillations on the position and strength of the South Pacific Convergence Zone. To critically examine the relationship between El Niño-Southern Oscillation (ENSO) events and the rainfall in Nadi and Suva in this study, the years with cold and warm events during the 1961-2003 period were identified and seasonal mean surface air temperatures and seasonal total rainfall amounts for those years were computed at Nadi and Suva. A two-tailed significance test was performed on the differences between the composite rainfalls for the samples representing the warm phases of El Niño versus that of the remaining (neutral plus La Niña) years and those representing the cold phases of La Niña versus remaining (neutral plus El Niño) years. 


\section{RESULTS}

\section{Climatological Surface Air Temperature and Rainfall Normals}

The mean monthly surface air temperatures and their extremes as inferred from averaging of daily data records collected for Nadi and Suva during the period from 1961 to 1990 are depicted in Figure 2. The annual average surface temperature was $25.4^{\circ} \mathrm{C}$ at both Nadi and Suva, with January and February being the warmest months with average daily temperatures exceeding $27.0^{\circ} \mathrm{C}$. The highest mean temperatures and their extremes at Nadi (Table 1) occurred in January and those at Suva occurred in February (Table 2). The daily maximum temperatures peaked at higher than $32{ }^{\circ} \mathrm{C}$ in February at both these locations. The nighttime temperatures showed a high of $24^{\circ} \mathrm{C}$ or more in February at both Nadi and Suva. Both Nadi and Suva exhibited the lowest daily mean temperatures in July. However, the mean nighttime temperatures for July in Suva $\left(20.5{ }^{\circ} \mathrm{C}\right)$ were higher than in Nadi $\left(17.8{ }^{\circ} \mathrm{C}\right)$ by about 2.5 ${ }^{\circ} \mathrm{C}$. The range of extremes in daily mean and maximum surface air temperatures was least in March and greatest in July at both locations. The range of extremes in daily minimum surface air temperature was also the least in March, but the range was greatest in July at Nadi with a secondary maximum in September; at Suva, the range of these extremes was the least in March and greatest in May with a secondary maximum in September.

Average annual mean daily surface air temperatures were $25.4{ }^{\circ} \mathrm{C}$ at both Suva and Nadi, and the range of extremes in the annual mean daily surface air temperature at these locations was also identical (high at $26.5^{\circ} \mathrm{C}$ and low at $24.4{ }^{\circ} \mathrm{C}$ ). However, as is evident from Tables 1 and 2, the average annual daytime maximum surface temperatures at Nadi (on the lee side of mountains) were $\sim 1.6^{\circ} \mathrm{C}$ higher than at Suva (on the windward side). This anomaly was least during summer $(0.3$ ${ }^{\circ} \mathrm{C}$ in March) and more pronounced in winter $\left(2.2^{\circ} \mathrm{C}\right.$ in July). It is interesting that the average annual nighttime minimum surface temperatures at Nadi were lower than at Suva by about $1.6^{\circ} \mathrm{C}$. This implies that the annual mean diurnal temperature range for Nadi (9.6 $\left.{ }^{\circ} \mathrm{C}\right)$ was larger than that for Suva $\left(6.5^{\circ} \mathrm{C}\right)$ on an average. Moreover, the diurnal temperature range in July was about $1{ }^{\circ} \mathrm{C}$ higher than in January at Nadi, but the reverse is true at Suva, suggesting a significant difference in the microclimate of the two locations examined in this study.

Due to the influence of the surrounding ocean, changes in the surface air temperature from day to day and from season to season at both these locations are, in general, relatively small. However, it is noteworthy that during the 1961-1990 period the lowest nighttime surface air temperature at Nadi was recorded at $11.3{ }^{\circ} \mathrm{C}$ on 7 August 1965 , and the highest nighttime surface air temperature here was recorded at $26.9{ }^{\circ} \mathrm{C}$ on 3 February 1962 (Table 1). At Suva, the lowest nighttime surface air temperature was recorded at $13.3{ }^{\circ} \mathrm{C}$ on 18 October 1965, and the highest nighttime surface air temperature was recorded at $27.6{ }^{\circ} \mathrm{C}$ on 24 March 1979 (Table 2). The highest daytime surface air temperature at Nadi was recorded at $36.7^{\circ} \mathrm{C}$ on 11 January 1987 , and the lowest daytime surface air temperature was recorded at $20.8^{\circ} \mathrm{C}$ on 2 August 1965. At Suva, the highest daytime surface air temperature was recorded at $34.5^{\circ} \mathrm{C}$ on 10 February 1987, and the lowest daytime surface air temperature was recorded at 21.0 ${ }^{\circ} \mathrm{C}$ on 18 June 1985.

Rainfall in Fiji is highly variable and mainly orographic (influenced by island topography and the prevailing southeast trade winds). The southeast trade winds are often saturated with moisture, causing any high landmass lying in their path to receive large amounts of precipitation. The mountains of Viti Levu create a wet climatic zone on their windward side and a dry climatic zone on their leeward side. The climatological normal for the period 1961-1990 shows that Suva (windward side) received an annual total rainfall of $304 \mathrm{~cm}$, but Nadi (leeward side) received a total of only about $181 \mathrm{~cm}$ rainfall annually on an average basis (Tables 1 and 2). The fact that the total annual rainfall at Nadi is only about $60 \%$ of that recorded at Suva highlights the dominating role of orog- 

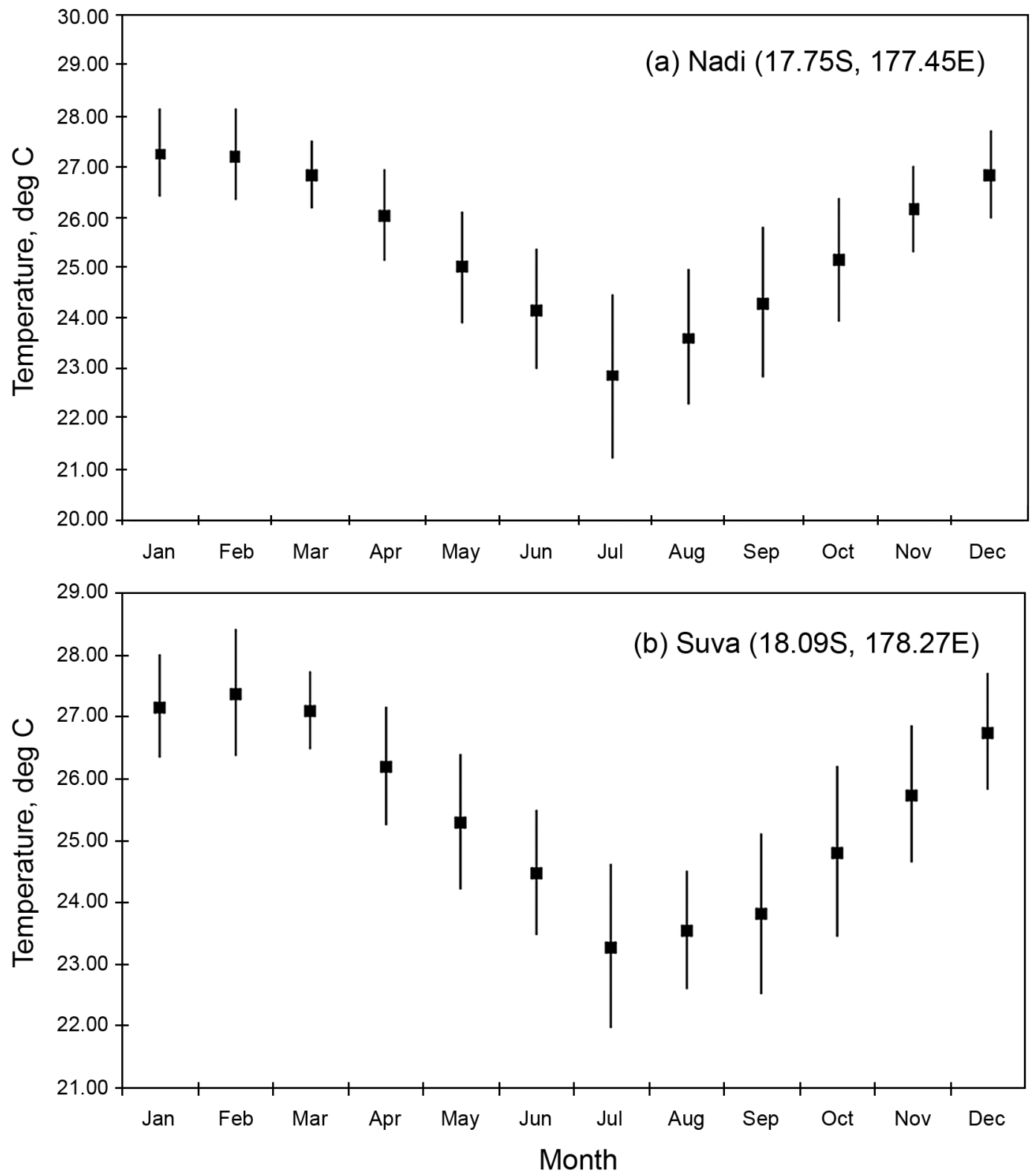

FigURE 2. Climatological monthly normal (1961-1990, mean, high, and low) average surface air temperatures at (a) Nadi and (b) Suva.

raphy in the spatial distribution of rainfall over Viti Levu Island. The highest annual total rainfall for the period 1961-1990 was recorded as $438 \mathrm{~cm}(144 \%$ of the normal) in 1975 at Suva and $298 \mathrm{~cm}(165 \%$ of the nor- mal) in 1974 at Nadi. Similarly, the lowest annual total rainfall for the period 19611990 was recorded as about $181 \mathrm{~cm}(60 \%$ of the normal) in 1987 at Suva and about $86 \mathrm{~cm}$ (48\% of the normal) in 1969 at Nadi. 


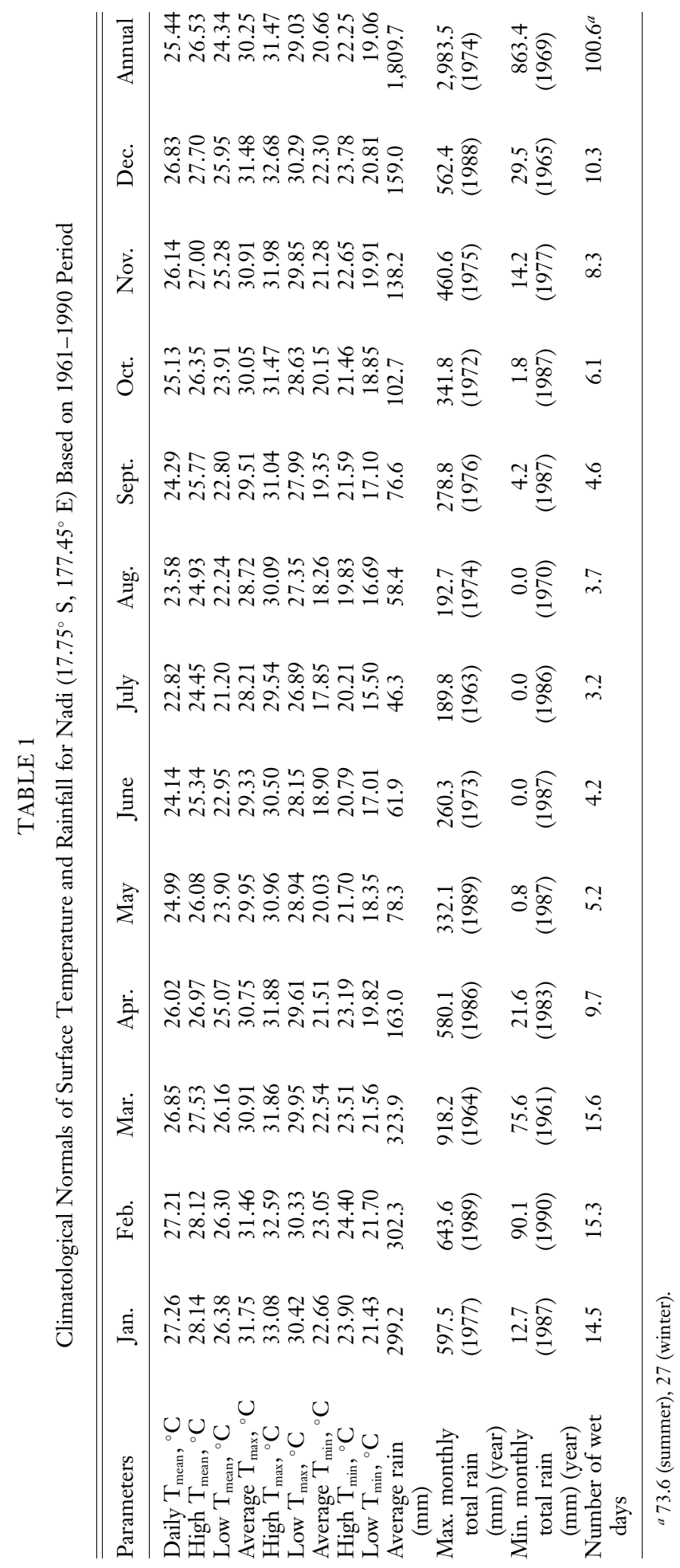




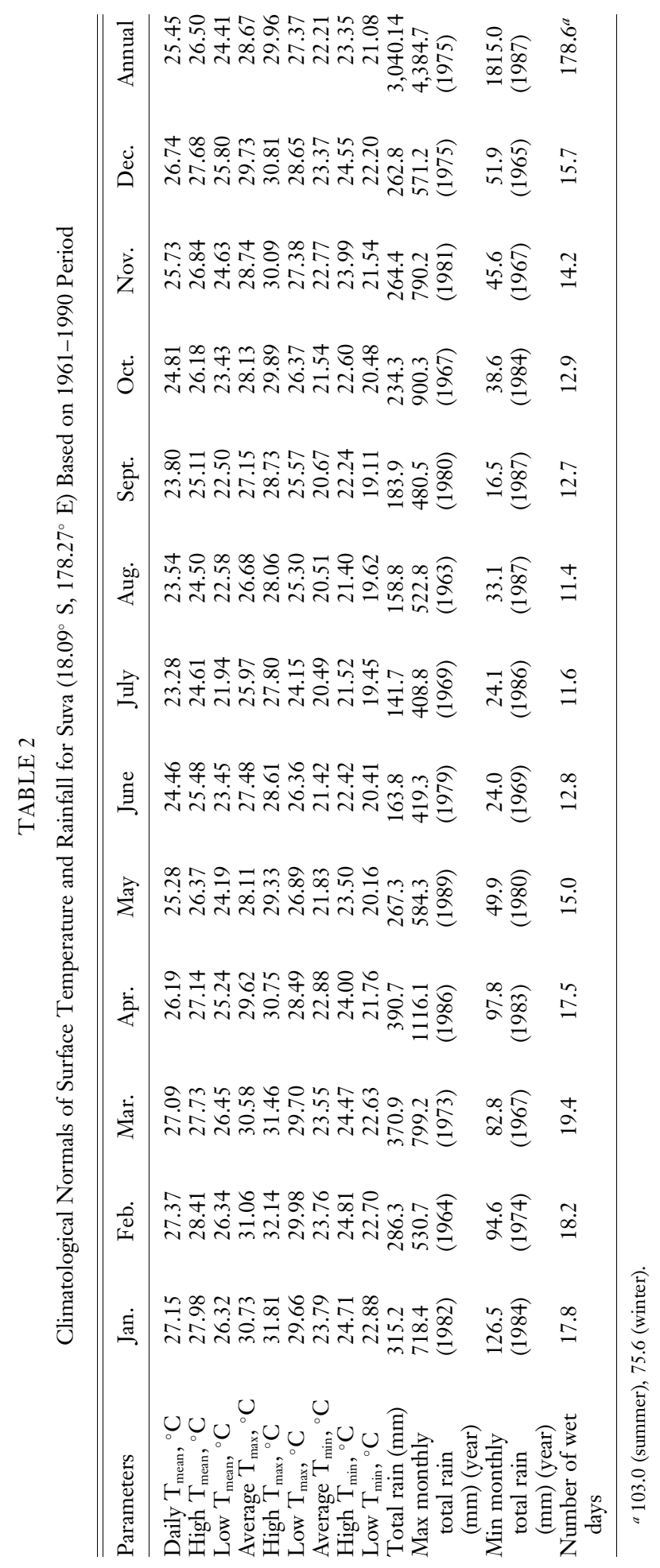


In general, Fiji experiences a distinct wet season (November to April) and a relatively dry season (May to October), largely controlled by the north and south movements of the South Pacific Convergence Zone, the main rainfall-producing system for the region. Nadi gets as much as $76.6 \%$ and Suva gets $62.2 \%$ of the annual total rainfall during the summer. Based on averages for the period from 1961 to 1990, the monthly total normal rainfall at Nadi peaked at $32.4 \mathrm{~cm}$ in March with a low of $4.6 \mathrm{~cm}$ in July (Tables 1 and 2). In Suva, the monthly total normal rainfall peaked at $39.1 \mathrm{~cm}$ in April with a low of 14.2 $\mathrm{cm}$ in July. The highest total rainfall was recorded in Nadi in March 1964 (91.8 cm) and in Suva in April 1986 (111.6 cm). No rainfall was reported at Nadi in July 1986 while Suva recorded the lowest monthly rainfall of 2.4 $\mathrm{cm}$. The climatological normal for number of wet days in a year was 101 days for Nadi and 179 days for Suva. Of these, Nadi had 74 wet days during summer and 27 wet days during winter on average, and Suva had 103 wet days during summer and as many as 76 days during winter. It is thus evident that the wet and dry seasons are more distinct at Nadi than at Suva and that Suva is wetter than Nadi both on a seasonal and an annual basis.

\section{Past and Current Climatic Trends}

Using the daily data records, trends in daily maximum, minimum, and mean temperatures and rainfall were analyzed from 1961 to 2003 for Nadi and Suva. Changes in temperature extremes were also studied. The analysis suggests that the average annual day mean temperatures registered increasing trends at both locations during the period 1961-2003. This trend was more prominent and statistically significant at Suva (at a rate of $0.25^{\circ} \mathrm{C}$ per decade). The rate of rise in average annual mean surface temperature at Nadi was only $0.07^{\circ} \mathrm{C}$ per decade. In contrast, the rate of increase in global mean surface air temperature in the twentieth century has been reported to be about $0.17{ }^{\circ} \mathrm{C}$ per decade (IPCC 2001a). From the average annual day mean temperature trends (Figure $3 a$ ) it is evident that the year 1998 was the warmest year at Nadi, when the annual mean surface air temperature peaked at $0.66{ }^{\circ} \mathrm{C}$ higher than the climatological normal of $25.4^{\circ} \mathrm{C}$, with 1988 and 2002 being the second and third warmest years (anomalies were $0.61{ }^{\circ} \mathrm{C}$ and $0.58{ }^{\circ} \mathrm{C}$, respectively). In Suva, the year 2001 was the warmest, when the annual mean surface air temperature peaked at $0.95{ }^{\circ} \mathrm{C}$ higher than the climatological normal of $25.4{ }^{\circ} \mathrm{C}$, with 1998 and 2002 being the next warmest years (anomalies were $0.90^{\circ} \mathrm{C}$ and $0.87^{\circ} \mathrm{C}$, respectively [Figure 4a]). Both Nadi and Suva experienced the lowest average annual daily mean surface air temperatures in the year 1965, with anomalies being $0.5^{\circ} \mathrm{C}$ and $0.7^{\circ} \mathrm{C}$, respectively, below the normal. At Nadi, the trend in annual mean maximum temperature is not significant, but the increasing trend displayed in annual mean minimum temperature is significant and is most prominent since the early 1990s when anomalies exceeded the $\pm 1 \sigma$ level (Figure $3 b, c$ ). At Suva, both maximum and minimum temperatures exhibit significant increasing trends (Figure $4 b, c$ ). The observed increases in nighttime minimum temperature at both Nadi and Suva (perhaps linked to a decline in cloud cover during the 1980s and 1990s relative to the 1960s and 1970s) are consistent with global mean nighttime minimum temperature, which has increased at twice the rate of daytime maximum temperatures during the period of 1950 to 2000 (IPCC 2001b).

Long-term precipitation changes in Nadi and Suva were also examined by studying the daily rainfall data over a period of $43 \mathrm{yr}$. No discernable increasing or decreasing trends were observed in the annual total rainfall at either of the two locations during the 19612003 period (Figure 5). The data show that both Suva and Nadi experience a maximum number of days with $\geq 30 \mathrm{~mm}$ of rainfall in March and a minimum number of days in July. There were no significant changes in heavy rainfall events (daily rainfall higher than $100 \mathrm{~mm}$ ) in recent years. For further investigation, we divided the whole period into two 20-yr intervals: 1961-1980 and 1981-2003. Two well-defined rainfall peaks occurred during summertime in both inter- 

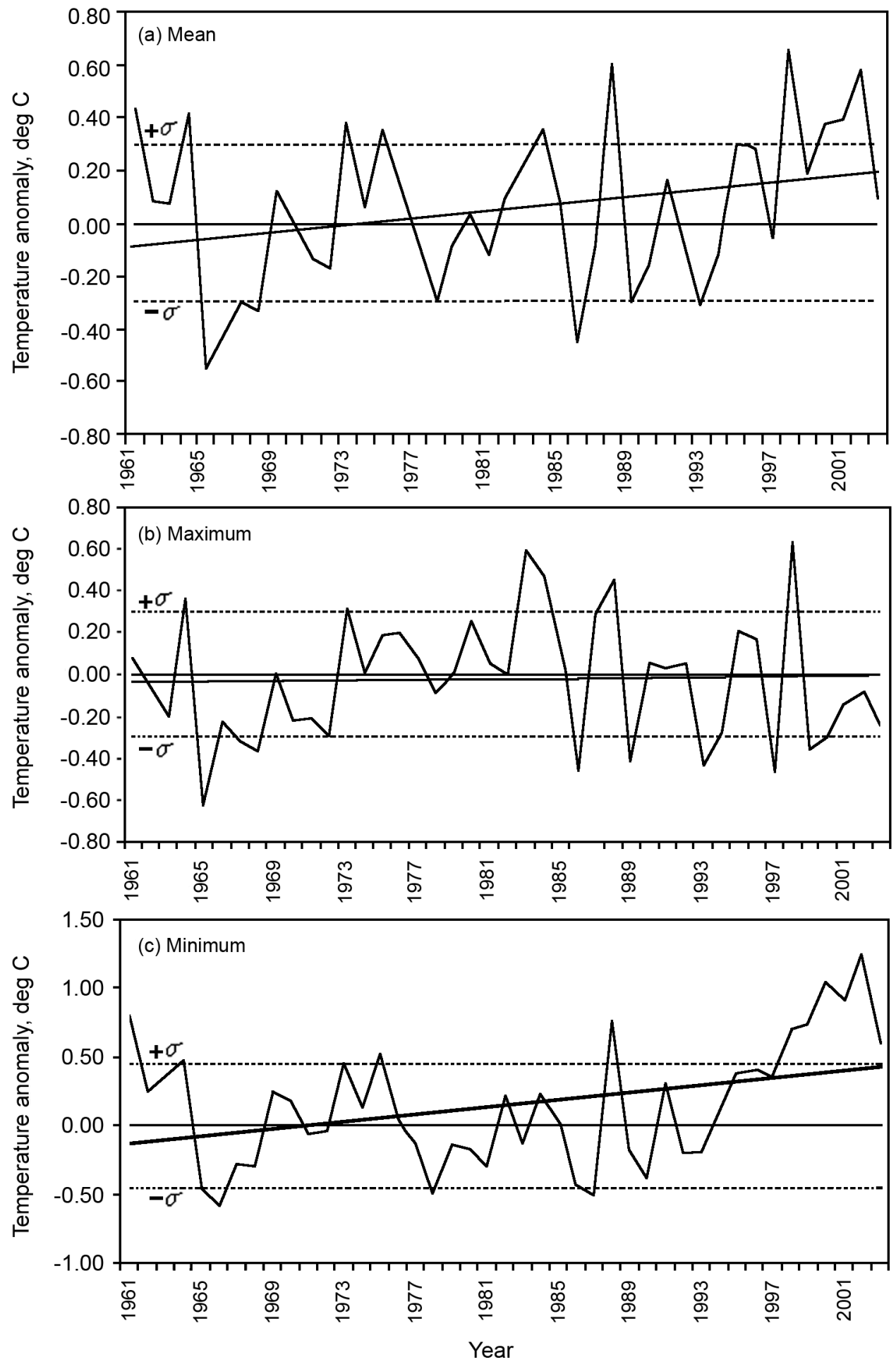

Figure 3. Trends in average day mean, maximum, and minimum surface temperature anomalies (departures with respect to 1961-1990 baseline period) at Nadi during the period from 1961 to 2003. 


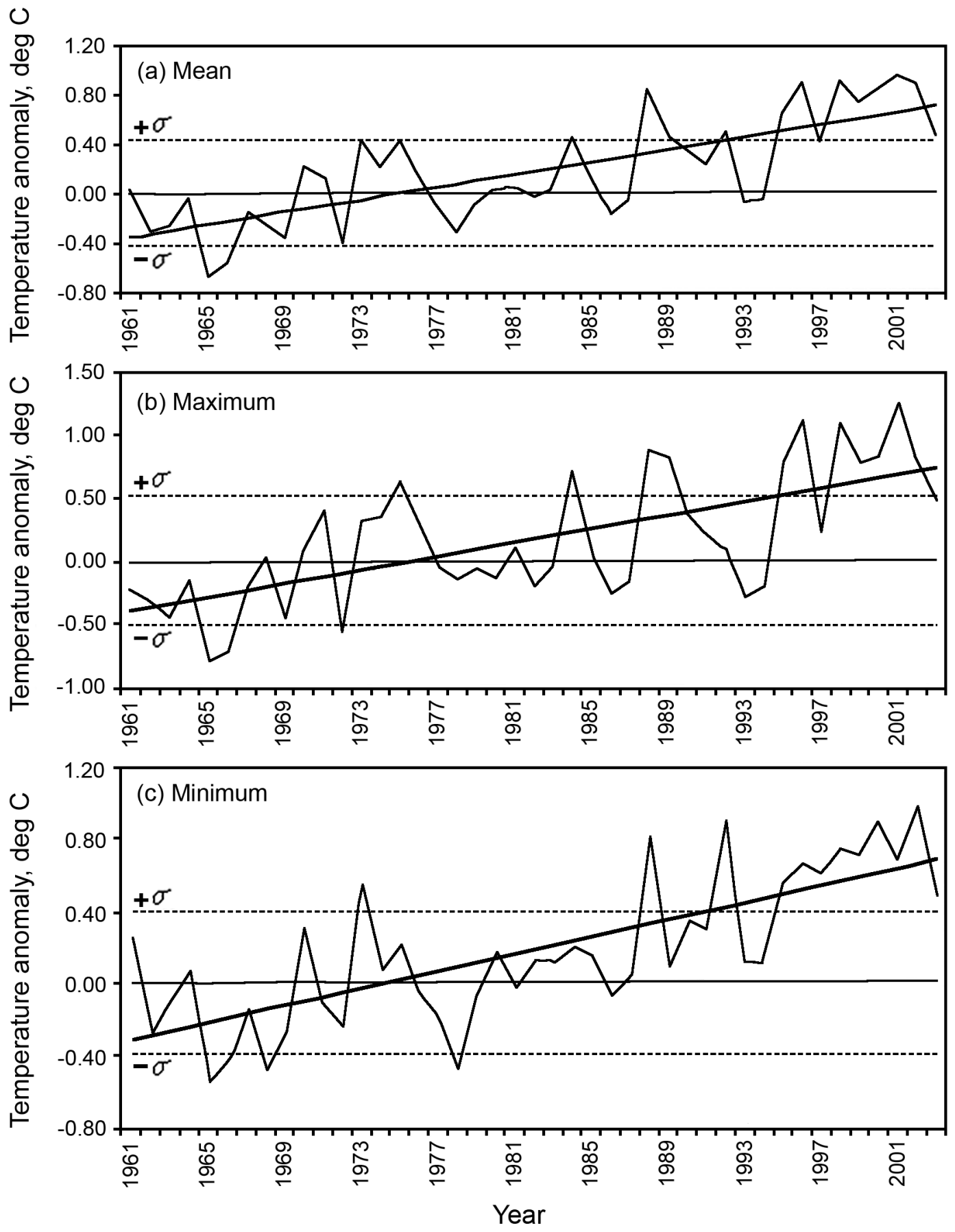

FIGURE 4. Trends in average day mean, maximum, and minimum surface temperature anomalies (departures with respect to 1961-1990 baseline period) at Suva during the period from 1961 to 2003. 

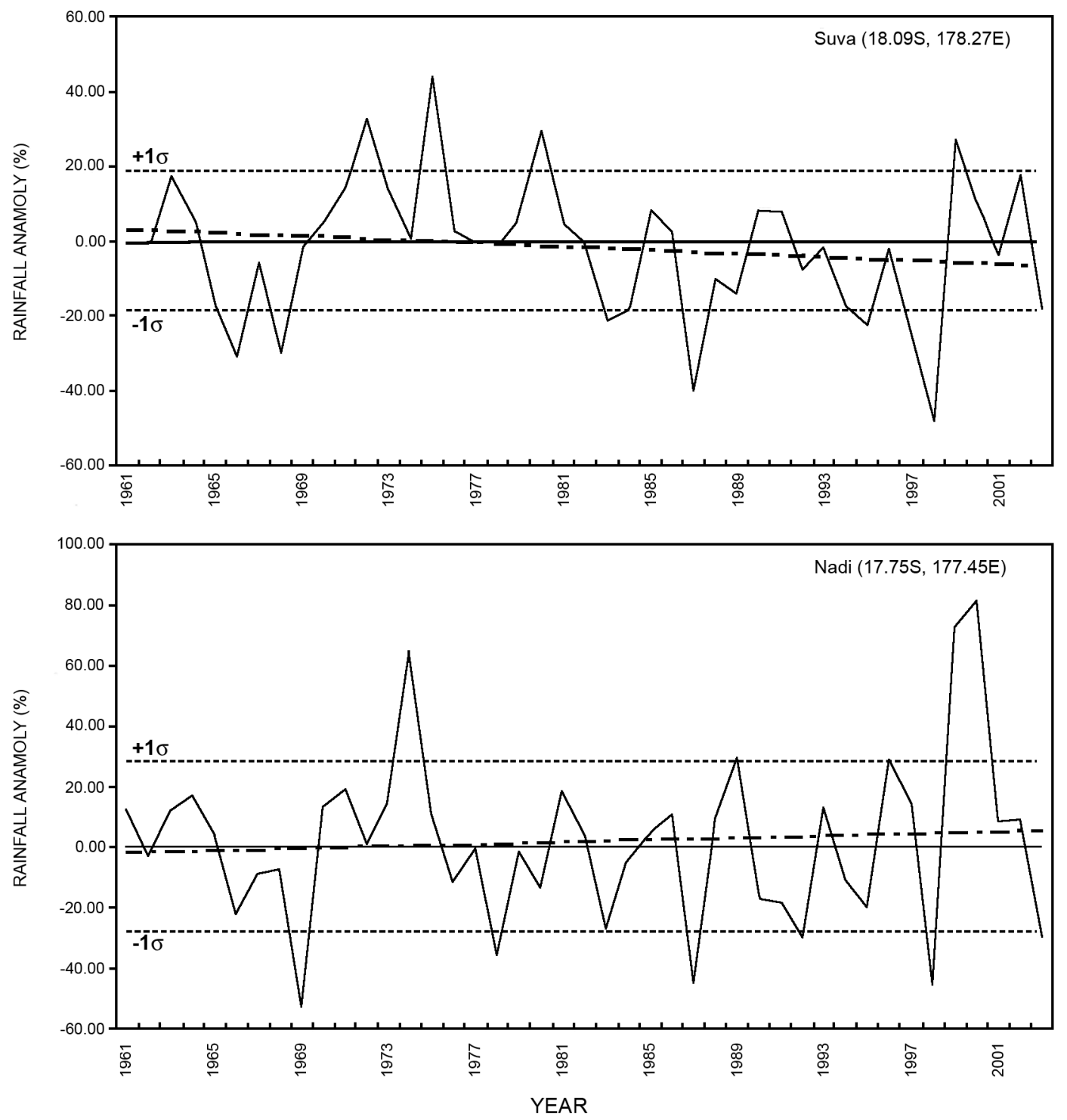

FIgURE 5. Trends in observed annual mean rainfall anomalies (\%) at Nadi and Suva during the 1961-2003 period.

vals in Suva. During the earlier interval, primary and secondary rainfall peaks were found in late March and early November, respectively. In the later interval, on the other hand, the primary peak was found in midApril, mainly attributed to enhanced heavy rainfall $(\geq 30 \mathrm{~mm} /$ day) events. Although a similar shift occurred in the secondary peak, it was much smaller. Thus, the relatively dry spell between the two peaks became longer in the later interval compared with the earlier one at Suva. At Nadi, however, only one welldefined rainfall peak occurred in March during summertime in both the time intervals. 
TABLE 3

Statistical Significance of Past and Current Trends in Surface Temperatures and Rainfall at Nadi and Suva

\begin{tabular}{|c|c|c|c|c|c|c|c|c|c|c|}
\hline \multirow[b]{2}{*}{ Statistics } & \multicolumn{5}{|c|}{ Suva } & \multicolumn{5}{|c|}{ Nadi } \\
\hline & 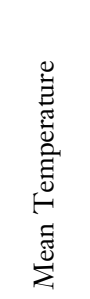 & 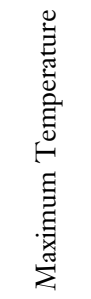 & 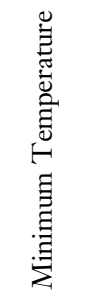 & 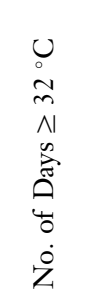 & 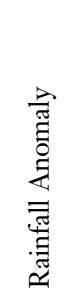 & 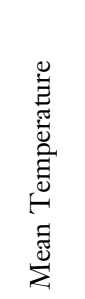 & 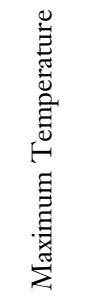 & 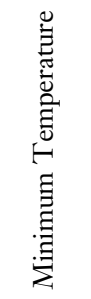 & 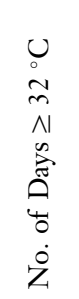 & 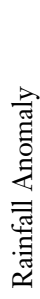 \\
\hline$P$ value ${ }^{a}$ & 0.000 & 0.000 & 0.000 & 0.000 & 0.312 & 0.061 & 0.841 & 0.015 & 0.757 & \\
\hline $\mathrm{R}^{2}(\mathrm{Ad})^{b}$ & $54.0 \%$ & $42.7 \%$ & $53.2 \%$ & $63.5 \%$ & $0.1 \%$ & $6.1 \%$ & $0.0 \%$ & $11.6 \%$ & $0.0 \%$ & \\
\hline
\end{tabular}

${ }^{a} P$ value: the smallest level of significance $(\alpha)$ for which the observed data indicate that the null hypothesis should be rejected.

${ }^{b} \mathrm{R}^{2}$ (Ad): the fraction of variance in $\mathrm{Y}$ (variable) accounted for by the variance in $\mathrm{X}$ (year) adjusted for degrees of freedom (linear regression equation).

\section{DISCUSSION}

\section{Trends in Surface Temperature and Rainfall}

The findings presented here suggest that the annual mean minimum nighttime temperatures have increased significantly (especially in Suva) during the past $43 \mathrm{yr}$ and at a much faster rate than the annual mean maximum daytime temperatures. As a consequence the diurnal temperature range has registered a declining trend at both locations. The observed decrease in diurnal temperature range is consistent with global observations of decrease in diurnal temperature range over land during the 1950 to 2000 period (IPCC 2001b). Meanwhile, annual mean maximum daytime temperature displayed no significant trend for Nadi (Table 3). However, increasing summer mean maximum temperatures are obvious at both locations, and the number of hot days during the season went up in the most recent decade. An examination of the changes in the frequency of extreme temperature events suggests that significant increases have taken place in the annual number of hot days and warm nights for both Suva and Nadi, with decreases in the annual number of cool days and cold nights at both locations. The number of hot days $\left(\mathrm{T}_{\max } \geq 32\right.$ $\left.{ }^{\circ} \mathrm{C}\right)$ showed a significant increasing trend
(Table 3), and the number of colder nights $\left(\mathrm{T}_{\min }<18{ }^{\circ} \mathrm{C}\right.$ ) showed a decreasing trend at Suva (Figure 6). A systematic increase in the 90th percentile of daily minimum temperatures was also observed. This increase was accompanied by a similar reduction in the number of colder days. There was a decline in the frequencies of cool days and an even stronger decreasing trend in the frequencies of cool nights.

The results of analysis on trends in extreme daily precipitation (defined as those larger than its 95 th percentile for the year) during summer and winter seasons for the period 1961-2003 indicate that there is little trend in total precipitation, but there are distinctive trends in seasonal patterns at both locations. The number of wet days per year (with at least $2.5 \mathrm{~mm}$ of rain per day) increased marginally at Nadi. No significant increase or decrease in normal rain days in winter or summer season or per year was detected at Nadi or Suva (Figure 7). The fraction of annual total rainfall from extreme events (events exceeding the 1961-1990 95th percentile), however, increased at both locations. The frequency of extreme rainfall events seems to have increased marginally but is not significant. Increasing trends in the average intensity of the wettest rainfall 

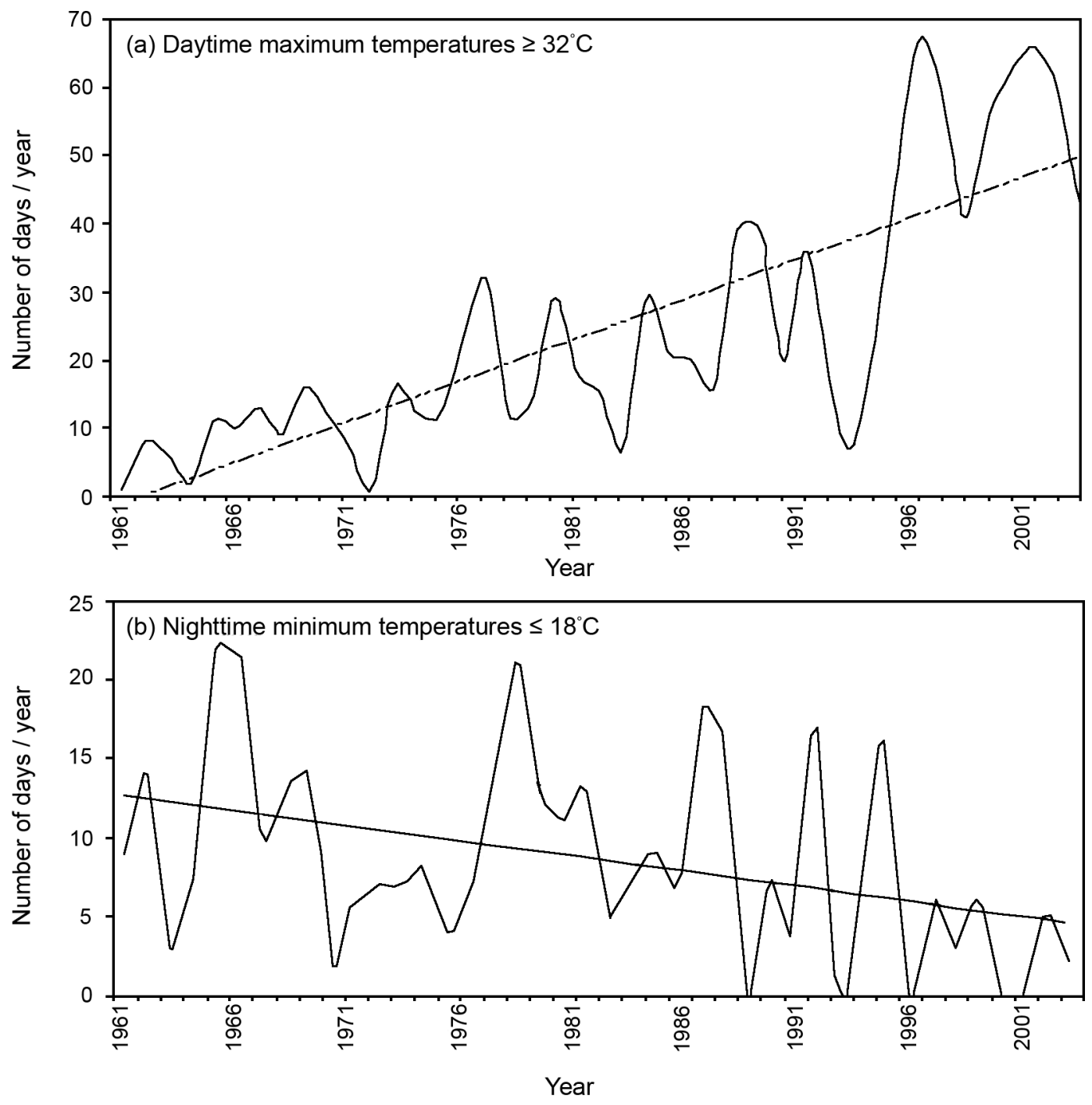

Figure 6. Trends in number of days in a year with (a) day maximum temperature exceeding $32{ }^{\circ} \mathrm{C}$ and $(b)$ night minimum temperature below $18^{\circ} \mathrm{C}$ at Suva during the $1961-2003$ period.

events each year were generally weaker at Nadi than at Suva but were not significant at either location.

\section{Climate Variability and Extreme Events}

El Niño has been recognized as the major cause of interannual variability in rainfall in Fiji and associated droughts. Conversely, during La Niña episodes rainfall is enhanced across the western equatorial Pacific. The changes in ocean temperatures during El Niño and La Niña events are also accompanied by large-scale fluctuations in air pressure known as the Southern Oscillation. The Southern Oscillation Index is one measure of the large-scale fluctuations in air pressure occurring between the western and eastern tropical Pacific (i.e., the state of the Southern Oscillation) during El Niño and La Niña epi- 

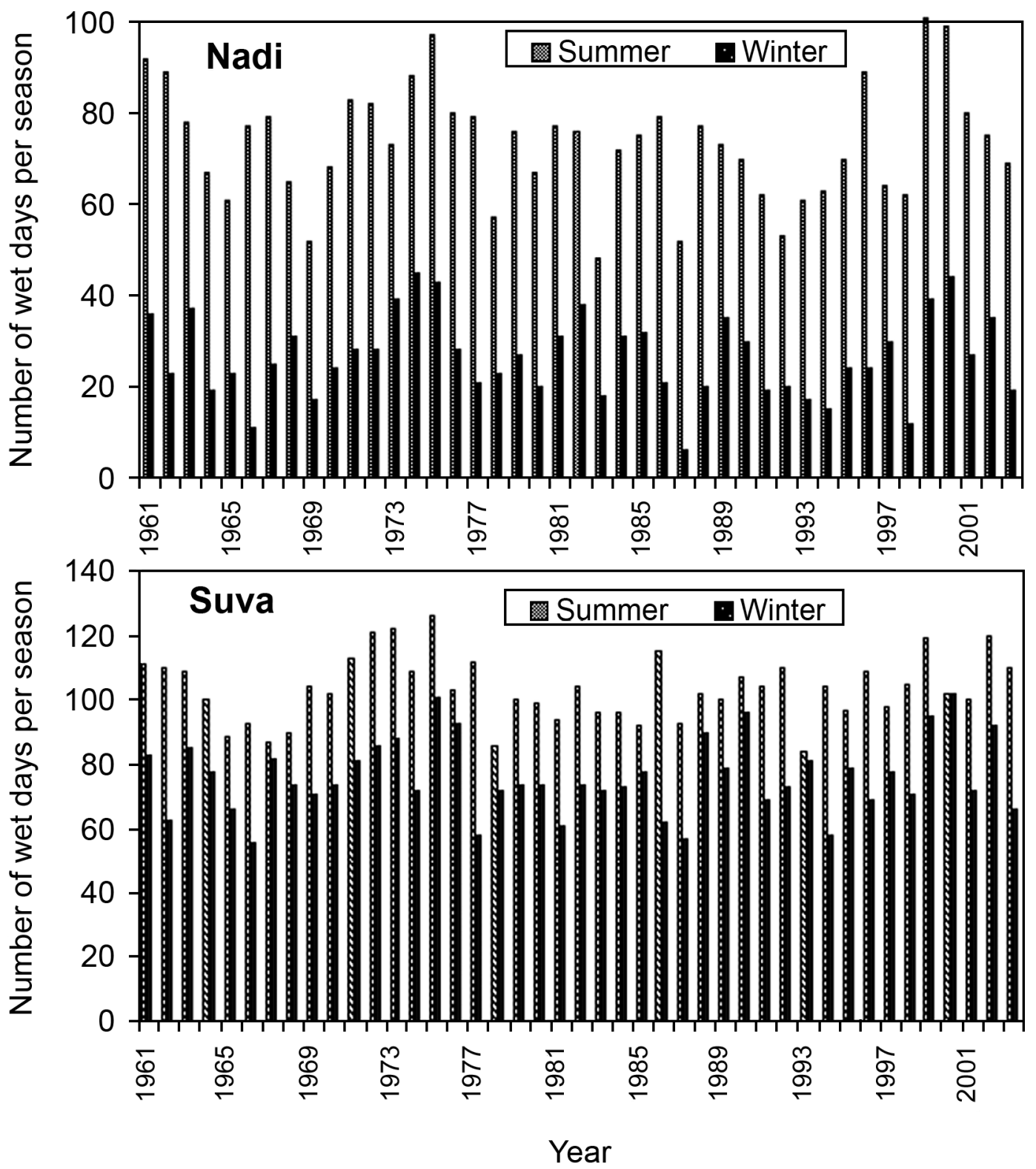

Figure 7. Trends in number of wet days during summer and winter seasons at Nadi and Suva during the 1961-2003 period.

sodes. Traditionally, this index is calculated based on the differences in air pressure anomaly between Tahiti and Darwin, Australia. Prolonged periods of negative Southern Oscillation Index values coincide with abnor- mally warm ocean waters across the eastern tropical Pacific typical of El Niño episodes. The presence of the El Niño events in the equatorial Pacific region shifts the weather systems and the tropical cyclones to the north 
and east of the dateline, decreasing the rainfall to the west of the dateline. The La Niña has the opposite effect and the weather systems are displaced to the south and east of the dateline, increasing the storminess and the rainfall episodes over the western Pacific and generally resulting in above-average rainfall in the region.

The 1980s and 1990s featured a very active ENSO cycle, with five El Niño episodes (1982/1983, 1986/1987, 1991-1993, 1994/ 1995, and 1997/1998) and three La Niña episodes (1984/1985, 1988/1989, 1995/1996) occurring during the period. This period also featured two of the strongest El Niño episodes of the century (1982/1983 and 1997/ 1998), as well as two consecutive periods of El Niño conditions during 1991-1995 without an intervening cold episode. El Niño conditions also prevailed during the year 2001-2002. During these El Niño episodes the main rain-producing system, the South Pacific Convergence Zone, was displaced north and eastward away from Fiji, resulting in suppressed rainfall in the western South Pacific region (Folland et al. 2002). However, geographically Fiji lies in the transition climatic zone from dry air (high-pressure region) to moist air (low-pressure region) of the Southwest Pacific, and the effects of El Niño on the rainfall of the two locations in Fiji considered here were not always distinct.

Seasonal mean surface air temperatures and seasonal total rainfall amounts at Nadi and Suva for the years with cold and warm events during the 1961-2003 period are listed in Table 4. Also, composite rainfall amounts for each of the two stations are plotted by ENSO status in Figure 8. The dotted line in this figure denotes the climatological mean rainfall for all years in the 1961-2003 period, the solid line the mean for the 12 composite El Niño years, and the dashed line the mean for the eight La Niña years. Vertical lines denote calendar year changes. Each plot shows composite rainfall for the period beginning about five seasons before the boreal winter of a mature episode and ending about five seasons after that winter. Differences between the composite rainfalls for the samples representing the warm phases of El Niño versus that of the remaining (neutral plus La Niña) years passing a two-tailed significance test at the 0.05 level are indicated with a hollow square along the solid line. Significant differences at the 0.05 level with respect to the La Niña composite rainfalls versus remaining (neutral plus El Niño) years are indicated in the figure with a solid square along the dashed line. It is clearly evident that a moderate to strong El Niño event has a significant impact on the rainfall at Nadi (in the western division of Fiji) leading to serious to severe drought conditions (Figure 8). Though a similar relationship holds true for the rainfall in Suva (central region) as well, the magnitude of impact is rather mild at Suva relative to that at Nadi.

Year-to-year (interannual) variability across Fiji is also related to the South Pacific Convergence Zone, a dominant feature of the atmospheric circulation in the Southwest Pacific that plays, in general, a pivotal role in both variability and trends in South Pacific climate. The South Pacific Convergence Zone occurs where the southeast trades from transitory anticyclones to the south meet with the semipermanent easterly flow from the eastern South Pacific anticyclone (Kiladis et al. 1989). The South Pacific Convergence Zone exists both in summer and winter, with approximately the same orientation and location. It appears that the South Pacific Convergence Zone moved eastward about $150 \mathrm{~km}$ around the year 1977 (Salinger et al. 2001). This has been confirmed from satellite pictures, which portray a shift in the longitude of the sea-level pressure trough and that of the minimum in outgoing longwave radiation. The latter is a measure of thunderstorm activity: the less longwave radiation is emitted into space, the colder the cloud tops are. This shift of the South Pacific Convergence Zone caused relatively drier conditions in Fiji, particularly in Suva. For example, the daily rainfall, sunshine, and cloud cover data suggest that Suva received $\sim 7 \%$ less rain and had $\sim 12 \%$ less clouds on an annual mean basis during the 1980s and 1990s relative to the 1960s and 1970s. At Nadi, however, these deviations are rather marginal and inconclusive. 


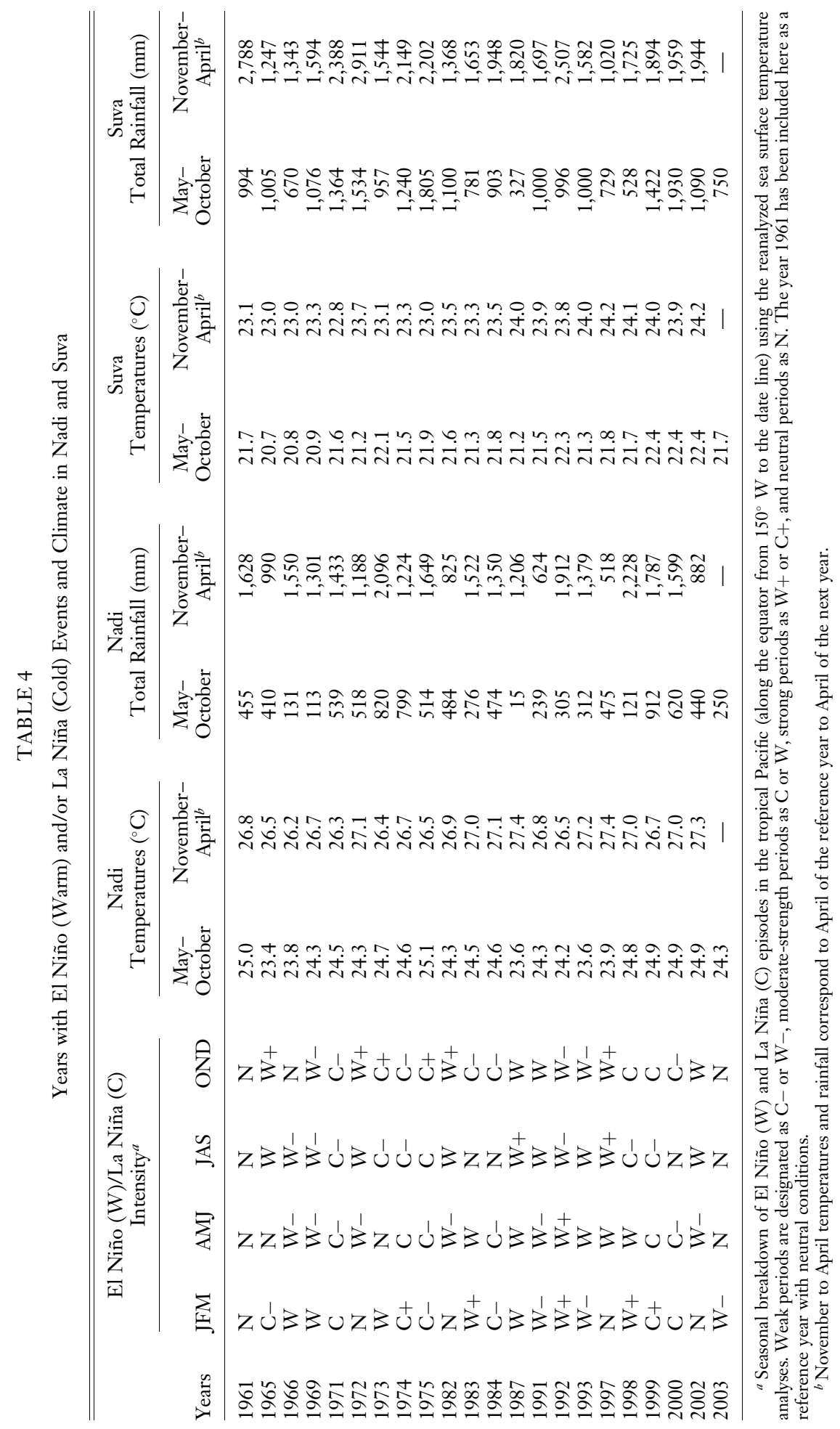



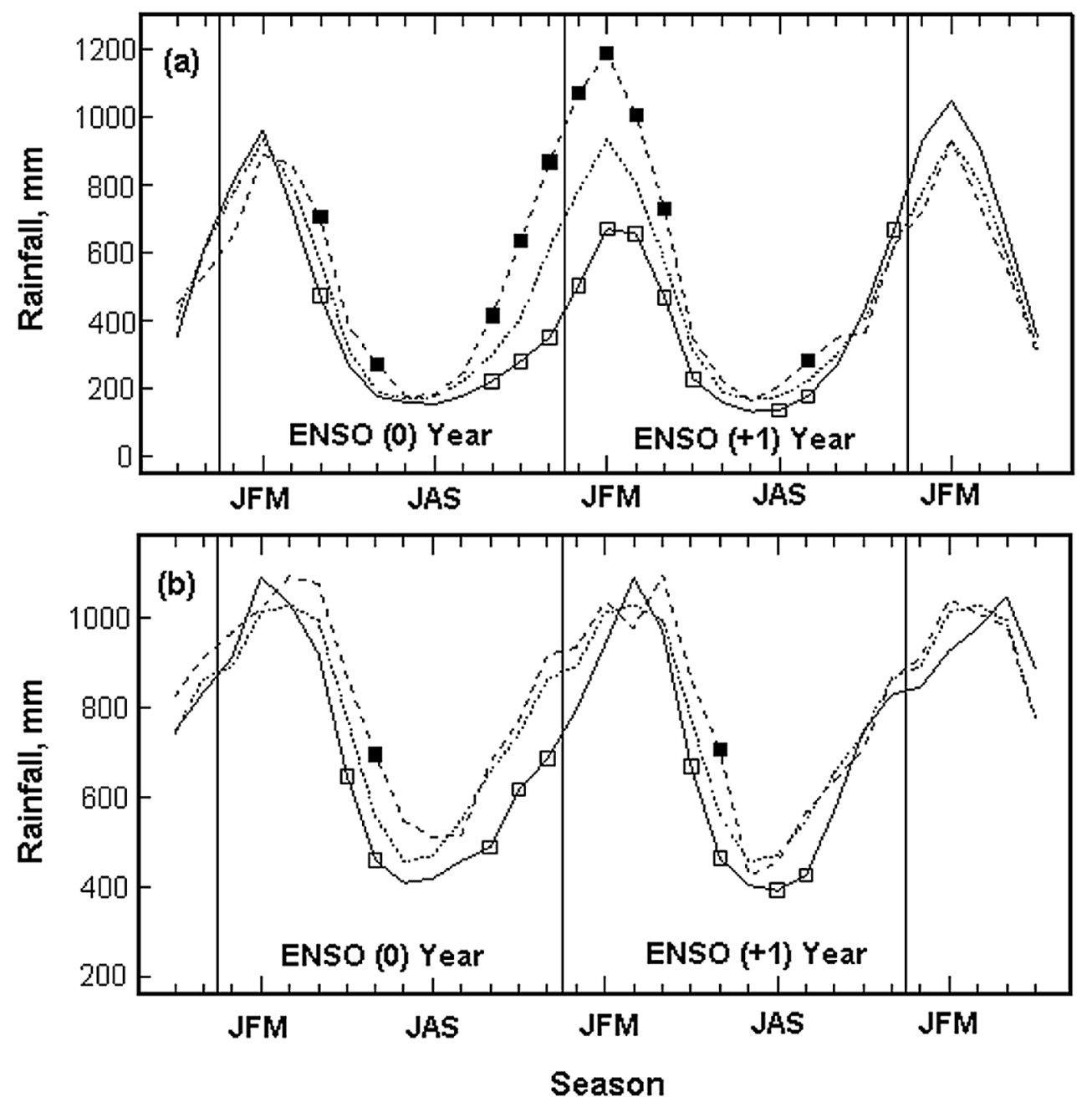

\section{Legends:}

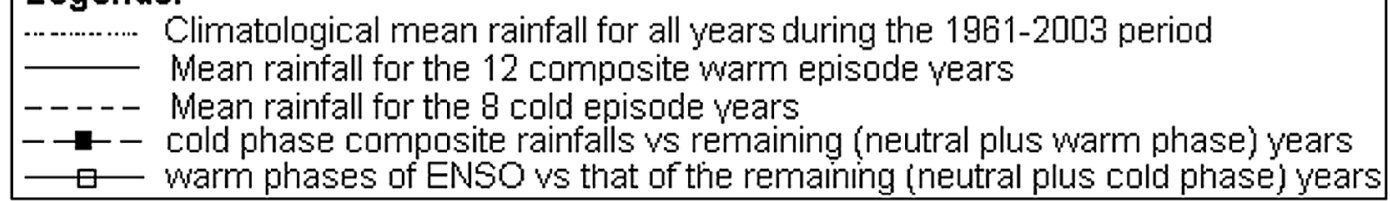

Figure 8. Relationship between ENSO events and rainfall at (a) Nadi and $(b)$ Suva.

Rainfall in Fiji also exhibits strong variability on subseasonal time scales. These fluctuations in rainfall often go through an entire cycle in 30-60 days and are referred to as "intra-seasonal oscillations" (also known as
"Madden-Julian Oscillation"). The MaddenJulian Oscillation is a naturally occurring component of the coupled ocean-atmosphere system and is regarded as the main fluctuation of atmospheric circulation that explains varia- 
tions of weather in the tropics (Madden 1986). Variation of the Madden-Julian Oscillation involves variations in wind, sea-surface temperature, cloudiness, and rainfall. The Madden-Julian Oscillation is characterized by a large-scale eastward movement of air in the upper troposphere with a period of about 20-70 days over the tropical eastern Indian and western Pacific Oceans at approximately $200 \mathrm{hPa}$ level (Rui and Wang 1990). During the summer the Madden-Julian Oscillation has a modulating effect on cyclonic activity in the western Pacific basin. The Madden-Julian Oscillation organizes convection into an eastward-propagating envelope of smaller-scale disturbances. This envelope moves eastward at between 5 and $10 \mathrm{~m} / \mathrm{sec}$ on average, generally forming in the tropical Indian Ocean and dissipating over the central Pacific (Madden and Julian 1994). In the tropical Pacific, summers with ENSO-neutral conditions are often characterized by enhanced 30- to 60-day Madden-Julian Oscillation activity. Such summers are also characterized by relatively small sea-surface temperature anomalies in the tropical Pacific compared with stronger warm and cold episodes (Hayashi and Golder 1993, Jones et al. 1998). In these summers there is a stronger linkage between the Madden-Julian Oscillation events and extreme precipitation events in the western South Pacific region (Jones and Weare 1996).

The Madden-Julian Oscillation seems to have a substantial impact on islands located in the western South Pacific that experience rainy seasons during both winter and summer seasons such as Fiji. These disturbances are responsible for many of the extreme precipitation events that are linked to flooding, as observed in preliminary scrutiny of records of synoptic scale disturbances over Suva and the daily rainfall records. Under the influence of Madden-Julian Oscillation, reversal of the trade winds (which blow from the South American coast toward Asia) also takes place, which generally triggers Kelvin waves and twin cyclones (Maloney and Kiehl 2002). The equatorial westerly winds generate an anticlockwise vortex in the Northern Hemisphere and a clockwise vortex in the Southern
Hemisphere. Twin cyclones, one in the Northern and one in the Southern Hemisphere, are common in the months of April, May, and June during ENSO-neutral years. The Southern Hemispheric cyclonic system contributes substantially to the intense rainfall over Fiji during those months. They also generate Kelvin waves that travel across the entire Pacific in about 1 to 2 months (Maloney and Hartmann 1998). The increase in frequency and strength of the Kelvin waves may even lead to warming in the east and initiation of an El Niño event.

Due to its slowly evolving nature, accurate prediction of the Madden-Julian Oscillation is fundamentally related to our ability to monitor the feature and to assess its relative position and strength. Dynamical models generally do not predict the Madden-Julian Oscillation well, partly because of the inherent difficulties that still remain regarding the correct mathematical treatment of tropical convective (rainfall) processes. Therefore, meteorologists have to use a variety of conventional data and analysis techniques to monitor, study, and predict tropical intraseasonal oscillations and their evolution. Satellite-derived data could be useful to indicate regions of strong tropical convective activity and regions in which the convective activity departs substantially from the longterm mean. These departures from normal are a fundamental diagnostic tool that should be used directly to monitor and predict the Madden-Julian Oscillation as it propagates over the islands located in the western South Pacific Ocean and hence enhance the forecasting skill of extreme precipitation events.

It is evident from our study that the moderate to strong ENSO events had a significant impact on the rainfall at Nadi (in the western division of Fiji) leading to severe drought conditions. Though a similar relationship exists for the rainfall in Suva (central region) as well, the magnitude of impact is rather mild at Suva relative to that at Nadi. The study further suggests that the twin cyclonic vortexes forming under the influence of Madden-Julian Oscillation and reversal of trade winds could contribute substantially to the intense rainfall events in Fiji in 
April, May, and June during ENSO-neutral years.

\section{ACKNOWLEDGMENTS}

We gratefully acknowledge the support of the Director of Meteorology, Fiji Meteorological Services, and the Head of Climate Services Division in providing relevant archived climatological data for this study.

\section{Literature Cited}

Derrick, R. A. 1951. Weather and climate. Pages 102-119 in The Fiji Islands. Fiji Government Press, Suva.

Folland, C. K., J. A. Renwick, M. J. Salinger, and A. B. Mullan. 2002. Relative influences of the Interdecadal Pacific Oscillation and ENSO on the South Pacific Convergence Zone. Geophys. Res. Lett. 29 (13): 1-4.

Hayashi, Y., and D. G. Golder. 1993. Tropical $40-50$ and 25-30 day oscillations. J. Atmos. Sci. 50:464-494.

IPCC. 2001a. Climate change 2001-The scientific basis. In J. T. Houghton et al., eds. Third Assessment Report of the Working Group I of Intergovernmental Panel on Climate Change. Cambridge University Press, United Kingdom.

IPCC. 2001b. Climate change 2001-The synthesis report. In R. T. Watson and the Core Writing Team, eds. A contribution of the Working Groups I, II and III to the Third Assessment Report of the Intergovernmental Panel on Climate Change. Cambridge University Press, United Kingdom.

Jones, C., and B. C. Weare. 1996. The role of low-level moisture convergence and ocean latent heat fluxes in the Madden and Julian Oscillation. J. Clim. 9:3086-3104.

Jones, C., D. E. Waliser, and C. Gautier.
1998. The influence of the Madden-Julian Oscillation on ocean surface heat fluxes and sea-surface temperatures. J. Clim. 11:1057-1072.

Kiladis, G. N., H. von Storch, and H. van Loon. 1989. Origin of the South Pacific convergence zone. J. Clim. 2 (10): 11851195.

Krishna, R. 1989. Climatology of Nadi Region for planning purposes. Fiji Meteorological Service Technical Information Circular 89:3.

Madden, R. A. 1986. Seasonal variations of the 40-50 day oscillation in the tropics. J. Atmos. Sci. 43:3138-3158.

Madden, R. A., and P. R. Julian. 1994. Observations of the 40-50 day tropical oscillation: A review. Mon. Weather Rev. 122:814-837.

Maloney, E. D., and D. L. Hartmann. 1998. Frictional moisture convergence in a composite lifecycle of the Madden-Julian Oscillation. J. Clim. 11:2387-2403.

Maloney, E. D., and J. T. Kiehl. 2002. MJOrelated SST variations over the tropical eastern Pacific during Northern Hemisphere summer. J. Clim. 15:675-689.

Prasad, R. 1979. Climate of Fiji. Fiji Meteorological Service, Nadi.

Rui, H., and B. Wang. 1990. Development characteristics and dynamic structure of tropical intraseasonal convection anomalies. J. Atmos. Sci. 47:357-379.

Salinger, M. J., J. A. Renwick, and A. B. Mullan. 2001. Inter decadal Pacific Oscillation and South Pacific climate. Int. J. Climatol. 21:1705-1722.

Sharma, S. K. 1982. Climatology of Nadi Region-Fiji. Fiji Meteorological Service, Technical Note 16:1-23. Nadi.

Twyford, I. T., and A. C. S. Wright. 1965. Climate. Pages 72-79 in The soil resources of the Fiji Islands. Eyre and Spottiswoode, London. 